\title{
Holocene environmental changes in Dicksonfjorden, west Spitsbergen, Svalbard
}

\author{
Young Ji Joo' ${ }^{1}$, Matthias Forwick², Kwangkyu Park', Youngjin Joe' ${ }^{1}$, Yeong Ju Son ${ }^{1} \&$ Seung-II Nam \\ 'Division of Polar Palaeoenvironment, Korea Polar Research Institute, Incheon, Republic of Korea; \\ ${ }^{2}$ Department of Geosciences, UiT-The Arctic University of Norway, Tromsø, Norway
}

\begin{abstract}
Multi-proxy analyses of two sediment cores from Dicksonfjorden were performed to reconstruct Holocene environmental conditions in this northern branch of Isfjorden, the largest fjord system in Svalbard. Factors affecting the depositional processes include shifts in sources of sediments, ice rafting and regional glacio-isostatic rebound. Sediments were derived from Palaeozoic siliciclastics and carbonates occurring at the fjord head and sides, respectively. Their relative contributions were controlled by falling relative sea level and the resulting progradation of the major stream and delta systems closer to the core sites. Deposition of clasts from sea-ice rafting persisted throughout most of the Holocene. Following a period of low, but continuous, clast fluxes (ca. 11 000-7000 calibrated years before the present), ice rafting was most intensive between ca. 7000 and 3000 calibrated years before the present. It can be related to extensive seasonal sea-ice formation caused by regional cooling. The prograding deltas also provided coarse sediments. Reduced ice rafting from ca. 3000 calibrated years before the present suggests enhanced formation of shorefast and/or permanent sea ice, suppressing sea-ice rafting in the fjord, in response to the cool climate and reduced heat flux from Atlantic Water. Episodic inflow of Atlantic Water and low turbidity of surface water can, however, account for a larger amount of marine organic matter produced in the outer fjord. The sedimentary record in Dicksonfjorden, where tidewater glaciers are absent, reflects similar climate and oceanographic variations as reconstructed in fjords on western Spitsbergen that are influenced by tidewater glaciers.
\end{abstract}

\section{Keywords}

Svalbard; fjord; ice rafting; geochemistry; granulometry; sea ice

\section{Correspondence}

Seung-II Nam, Division of Polar

Palaeoenvironment, Korea Polar Research Institute, 26 Songdomirae-ro, Incheon 21990, Korea. E-mail: sinam@kopri.re.kr

\author{
Abbreviations \\ AMS: accelerator mass spectrometry \\ cal. years BP: calibrated years before 1950 \\ ${ }^{14} \mathrm{C}$ years BP: uncalibrated years before 1950 \\ $\delta^{13} \mathrm{C}$ : carbon isotope composition of \\ organic matter \\ Ky: thousands of years \\ Kya: thousands of calibrated years ago \\ $\mathrm{N}_{\text {inorg }}$ : inorganic nitrogen \\ $\mathrm{N}_{\text {org }}$ : organic nitrogen \\ OM: organic matter \\ TC: total carbon \\ TIC: total inorganic carbon \\ $\mathrm{TN}$ : total nitrogen \\ TOC: total organic carbon \\ UiT: UiT-The Arctic University of Norway \\ XRF: $x$-ray fluorescence
}

To access the supplementary material, please visit the article landing page

\section{Introduction}

Since the termination of the last deglaciation, which dates back to ca. 11.3-11.2 Kya in Isfjorden and its branches (e.g., Mangerud et al. 1992; Elverhøi et al. 1995; Svendsen et al. 1996; Svendsen \& Mangerud 1997; Forwick \& Vorren 2009; Baeten et al. 2010), the fjords on western Spitsbergen have been subject to environmental changes driven by climate and oceanographic variations. The area also underwent post-glacial crustal rebound leading to relative sealevel fall with declining rates in the Holocene (Salvigsen 1984; Forman et al. 2004; Lønne \& Nemec 2004).

The early Holocene was a relatively warm period, with strong inflow of warm Atlantic Water, as well as reduced sea-ice formation and glacier extents on Spitsbergen (e.g.,
Svendsen \& Mangerud 1997; Hald et al. 2004; Forwick \& Vorren 2007, 2009; Baeten et al. 2010; Rasmussen et al. 2012; Røthe et al. 2015; Farnsworth et al. 2017; Mangerud \& Svendsen 2018; van der Bilt et al. 2018). An early Holocene seawater temperature reconstruction for Dicksonfjorden exemplifies an amplified effect of warming $\left(+4-6^{\circ} \mathrm{C}\right)$ at high latitudes relative to global estimates $\left(+1-3^{\circ} \mathrm{C}\right.$; Beierlein et al. 2015). The early Holocene warmth culminated with a stepwise regional cooling, influenced by decreasing insolation, starting at ca. 9-8.8 Kya (Svendsen \& Mangerud 1997; Hald et al. 2004; Forwick \& Vorren 2009; Rasmussen et al. 2012; Mangerud \& Svendsen 2018). The reduced heat flux from warm Atlantic Water resulted in the growth of glaciers on western Spitsbergen, with glacier expansions occurring at different times (Svendsen 8 
Mangerud 1997; Forwick \& Vorren 2007, 2009; Baeten et al. 2010; Forwick et al. 2010). Although the inflow of Atlantic Water to central Isfjorden persisted during the middle Holocene, the effect of heat transport was counteracted by the insolation and freshwater forcings, resulting in cooling of this water mass (Rasmussen et al. 2012). Cool, but variable, conditions persisted during the late Holocene, as observed on the continental margin and fjords in western Spitsbergen (Svendsen \& Mangerud 1997; Forwick \& Vorren 2007, 2009; Baeten et al. 2010; Rasmussen et al. 2012; Jernas et al. 2013; Mangerud \& Svendsen 2018).

Reconstructions of environmental conditions from fjord sediments can be opposing within the same fjord system: tidewater glaciers, for instance, appear to have been (1) absent during the early to middle Holocene in the mouth and inner part of Isfjorden (Elverhøi et al. 1995; Svendsen \& Mangerud 1997) or (2) present throughout the Holocene in the centre and head of Isfjorden, with fluctuations at different times (Forwick \& Vorren 2009; Baeten et al. 2010; Forwick et al. 2010). While sediments from fjords on western Spitsbergen affected by the presence of tidewater glaciers are known to archive local and regional changes in climate and oceanographic conditions (Svendsen \& Mangerud 1997; Forwick \& Vorren 2009; Baeten et al. 2010; Forwick et al. 2010; Rasmussen et al. 2012), Holocene palaeoenvironmental reconstructions from fjords without tidewater glaciers are yet to be generated.

The overall objective of this study is to investigate Holocene environmental conditions in Dicksonfjorden, one of the northern branches of the Isfjorden system, Svalbard (Fig. la), based on multi-proxy analyses of two sediment cores, including lithostratigraphy, granulometry and inorganic and bulk OM geochemistry (carbon isotopes),

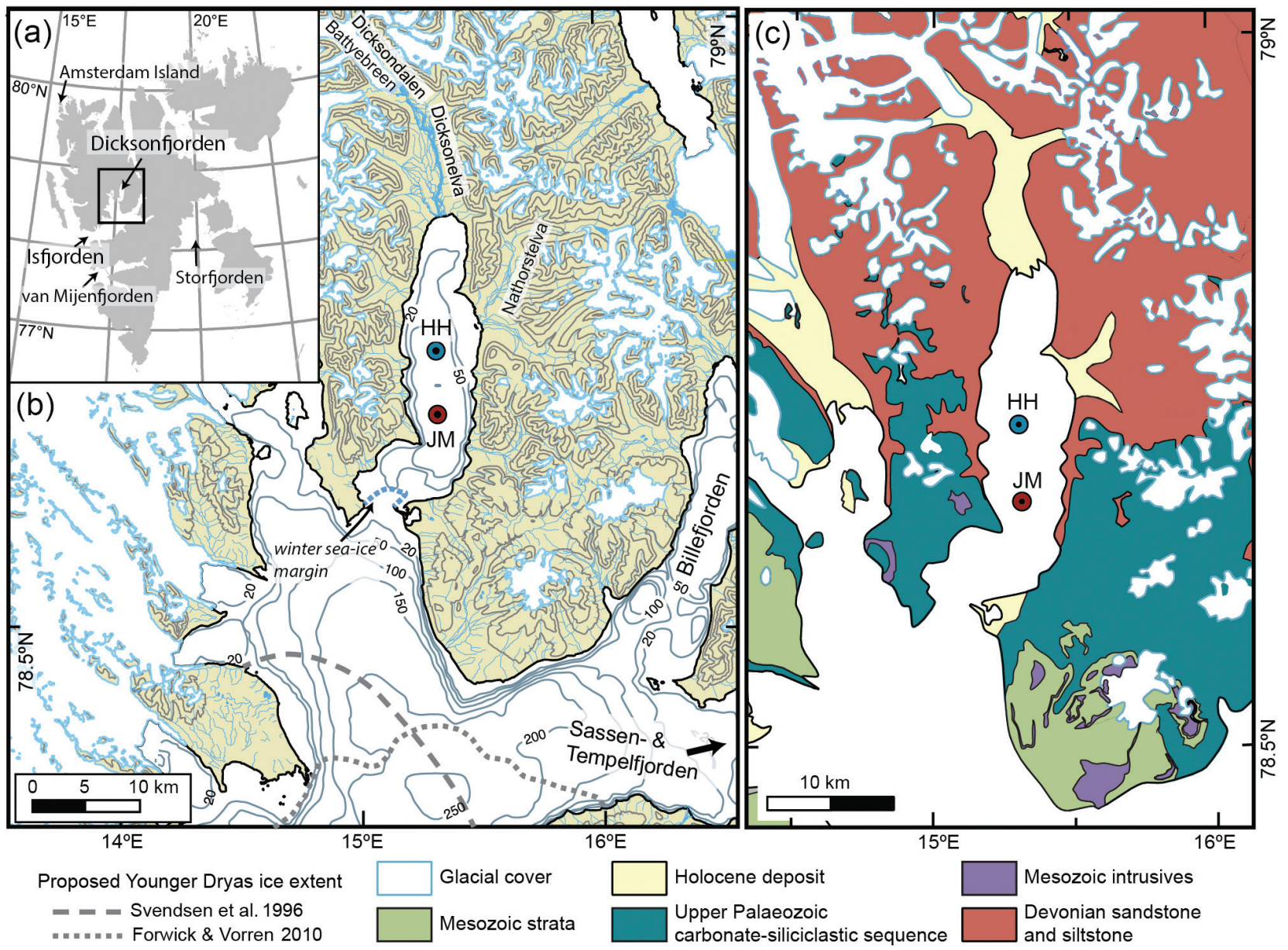

Fig. 1 (a) Map of Svalbard and Dicksonfjorden showing the locations of JM05-046-GC (JM) and HH16-1202-GC (HH), along with (b) topography, bathymetry, shoreline and distribution of glaciers and (c) bedrock geology of the area. The interval of the contour lines on land in the topographic map is $200 \mathrm{~m}$. The geologic map is modified after Dallmann \& Elvevold (2015). Winter sea-ice margin in Dicksonfjorden is from a satellite image of the Norwegian Polar Institute (https://toposvalbard.npolar.no). 
supplemented by radiocarbon age determination. Unlike most other fjords in Svalbard, tidewater glaciers are absent in Dicksonfjorden. Furthermore, Dicksonfjorden has a comparatively shallow sill at its mouth, where the water depth is maximally ca. $45 \mathrm{~m}$, largely separating the fjord hydrographically from the rest of the Isfjorden system. The sedimentary record therefore primarily documents variations in riverine input from a major braided-river system in the fjord head and minor rivers along the fjords sides, as well as sea-ice rafting.

\section{Regional setting of study area}

Dicksonfjorden is a north-south-oriented fjord that is ca. $30 \mathrm{~km}$ long and ca. $7 \mathrm{~km}$ wide. Its catchment area is approximately $1013 \mathrm{~km}^{2}$, of which $28 \%$ is covered by glaciers (Hagen et al. 1993). All glaciers in the drainage area of Dicksonfjorden terminate onshore. Located in the valley of Dicksondalen, the largest glacier Battyebreen (130 $\mathrm{km}^{2}$ in area and $24 \mathrm{~km}^{3}$ in volume; Hagen et al. 1993) terminates ca. $23 \mathrm{~km}$ north of the fjord head (Fig. lb). Meltwater emanating from this glacier is transported to Dicksonfjorden via the river Dicksonelva. In the northeastern part of the inner fjord, a river system named Nathorstelva runs through the valley of Nathorstdalen (Fig. lb). Even though continuous measurements from Dicksonfjorden are absent, measurements from other river systems draining into western Spitsbergen fjords reveal that meltwater and sediment transport occurs from late May/early June to late September/early October; the rivers are frozen during the rest of the year (Prior et al. 1981; Weslawski et al. 1995; Svendsen et al. 2002). Tidal (mud) flats are formed at the mouths of the two rivers (Kvam 2018). Maximum water depth is ca. $123 \mathrm{~m}$ in the southern part of the fjord. A sill with a water depth of ca. $45 \mathrm{~m}$ crosses the fjord mouth. Sea ice in Spitsbergen fjords forms typically from November and sea-ice break-up occurs between April and July (Svendsen et al. 2002; Nilsen et al. 2008). Large interannual variations of the timing of sea-ice formation and sea-ice extent occur (Cottier et al. 2007). However, sea-ice extent has been declining since the past decades (e.g., Muckenhuber et al. 2016).

Fluvial siltstones and sandstones of the Devonian Wood Bay Formation, which represent the Devonian Old Red Sandstone in Spitsbergen (Dallmann \& Elvevold 2015), occupy the largest area at the inner fjord and the proximal drainage of Dicksonelva further north. Carboniferous-Permian mixed carbonate-siliciclastic strata are found on the sides of the central fjord (Fig. 1c).

\section{Materials and methods}

\section{Sample collection}

Multi-proxy analyses of two sediment gravity cores provide the basis for this study. The cores JM05-046-GC (JM) and HH16-1202-GC (HH) were retrieved during cruises of the UiT's RV Jan Mayen/Helmer Hanssen in 2005 and 2016, respectively (see Table 1 for details). The wetbulk density and magnetic susceptibility of the HH core were measured in $1 \mathrm{~cm}$ steps using a GEOTEK Multi-Sensor Core Logger at UiT. X-radiographs of half-core sections ( $\mathrm{HH}$ core) were acquired at UiT, and $\mathrm{x}$-radiographs of 1-cm-thick core slabs (JM core) were acquired at the Korea Polar Research Institute. Up to $10 \mathrm{~g}$ of sediment was sub-sampled at $5-10 \mathrm{~cm}$ spacing throughout the cores for further analyses, as described below.

\section{Sample treatments and analyses}

After freeze-drying, each sample was split into three subsamples: one for radiocarbon dating and grain size analysis and two for geochemical analyses. One subsample for the geochemical analyses was powdered and acidified using hydrochloric acid $(2 \mathrm{~N})$ for $24 \mathrm{hr}$ to remove carbonate. It was rinsed three times with deionized water and freeze-dried prior to measurements of TOC and the carbon isotope composition of OM. The other subsample was first powdered and split into two aliquots: one without further chemical treatment for TC and TN contents measurement, and the other subsample was treated with $\mathrm{KOBr}-\mathrm{KOH}$ solution to remove $\mathrm{N}_{\text {org }}$ for separating $\mathrm{N}_{\text {inorg }}$ (Silva \& Bremner 1966).

Both intact and fragmented marine mollusc shells (bivalves, snails, etc.) were picked from the untreated bulk-sediment subsample for AMS ${ }^{14} \mathrm{C}$ dating. The AMS ${ }^{14} \mathrm{C}$ analysis was performed at the Beta Analytic Laboratory in Miami, FL. All ${ }^{14} \mathrm{C}$ dates were calibrated to calendar ages applying the Calib7.01 programme and the Marine 13 data set (Stuiver \& Reimer 1993; Reimer et al. 2013). A regional average $\Delta R$ value of $93 \pm 23$ for Spitsbergen from the marine reservoir correction database

Table 1 Core locations, water depths and recoveries of the cores used in this study.

\begin{tabular}{lccc}
\hline Core & Latitude (N) & Longitude (E) & Water depth (m) \\
\hline JM05-046-GC & $78^{\circ} 40.50^{\prime}$ & $15^{\circ} 18.89^{\prime}$ & 88 \\
HH16-1202-GC & $78^{\circ} 43.63^{\prime}$ & $15^{\circ} 18.58^{\prime}$ & 299 \\
\hline
\end{tabular}


Table 2 AMS ${ }^{14} \mathrm{C}$ dates and calibrated dates for JM05-046-GC and HH16-1202-GC.

\begin{tabular}{|c|c|c|c|c|c|}
\hline Core & Depth $(\mathrm{cm})$ & Material & ${ }^{14} \mathrm{C}$ age $\left({ }^{14} \mathrm{C}\right.$ years $\left.\mathrm{BP}\right)$ & Calibrated age $\pm 2 \sigma($ cal. years BP) & Date used in age model (cal. years BP) \\
\hline JM05-046-GC & 72 & bivalve fragments & $2490 \pm 30$ & 1919-2135 & 2027 \\
\hline JM05-046-GC & 232 & unidentified fragments & $7810 \pm 30$ & $8063-8297$ & 8180 \\
\hline JM05-046-GC & 246 & bivalve fragments & $8390 \pm 30$ & $8704-8983$ & 8844 \\
\hline JM05-046-GC & 282 & bivalve fragments & $9160 \pm 30$ & $10224-10461$ & 10343 \\
\hline JM05-046-GC & 292 & bivalve fragments & $9790 \pm 40$ & $10477-10727$ & 10602 \\
\hline $\mathrm{HH} 16-1202-\mathrm{GC}$ & 214 & mollusc fragments & $4580 \pm 30$ & $4555-5084$ & 4680 \\
\hline HH16-1202-GC & 244 & mollusc fragments & $6120 \pm 30$ & $6332-6553$ & 6443 \\
\hline
\end{tabular}

(http://radiocarbon.pa.qub.ac.uk/marine/) was applied to correct the ${ }^{14} \mathrm{C}$ dates. The midpoints of the calibrated ages $( \pm 1 \sigma)$ were chosen to build age models (Table 2 ), assuming uniform sedimentation rate between the dated levels. The ages reported throughout this article are in Kya unless otherwise indicated.

The grain-size distribution of the bulk-sediment samples was measured every $10 \mathrm{~cm}$ in both cores using a Malvern Mastersizer 2000 Laser Particle Size Analyzer. Each sample was treated with $10 \%$ hydrogen peroxide to remove $\mathrm{OM}$ and sonicated prior to the analysis. Clasts larger than $2 \mathrm{~mm}$ were regarded to be ice-rafted debris and counted every $1 \mathrm{~cm}$ from x-radiographs (see Grobe 1987). As the top $22 \mathrm{~cm}$ of the JM core was disrupted during previous subsampling, this interval was excluded from x-radiography and, therefore, clast counting. Clast fluxes were calculated based on sedimentation rates in both cores.

Weight percentages of TC, TOC, TN and $\mathrm{N}_{\text {inorg }}$ and carbon isotope composition of OM were measured using a Thermo Delta V Isotope Ratio Mass Spectrometer connected to a Thermo Flash 2000 CHNS/OH Elemental Analyzer by means of continuous flow, operated at the Korea Polar Research Institute. TIC contents were obtained by subtracting TOC contents from TC. Likewise, $\mathrm{N}_{\text {org }}$ was determined by subtracting $\mathrm{N}_{\text {inorg }}$ from TN. $\delta^{13} \mathrm{C}_{\text {org }}$ values are reported in per mil notation relative to Vienna Pee Dee Belemnite International Standard. Reference gases were calibrated relative to Indiana University Acetanilide \#1, USGS40, Urea and Thermo Soil standards. Randomly selected samples were run in duplicate to test sample variability. Analytical precision is within $0.2 \%$.

Qualitative element-geochemical measurements of the cores were performed on the archive core halves using an Avaatech XRF core scanner operated at the Korea Institute of Geoscience and Mineral Resources (JM core) and at UiT (HH core). The disrupted, top ca. $22 \mathrm{~cm}$ of the JM core was excluded from the measurement. The detailed settings for XRF measurements are summarized in Supplementary Table S1. The cores were adjusted to room temperature prior to the measurements. We avoided using light elements such as $\mathrm{Si}$ and $\mathrm{Al}$ because they are known to be sensitive to scattering and adsorption of $\mathrm{x}$-rays by water (Tjallingii et al. 2007; Weltje \& Tjallingii 2008). To resolve closed-sum effects, ratios between elements, rather than counts of a single element, were used for this study (Tjallingii et al. 2007; Weltje \& Tjallingii 2008).

Major and trace element compositions of the four bedrock samples (Devonian sandstone, Carboniferous siltstone, Carboniferous-Permian calcareous shale and Permian mudstone) and eight sediment samples (four from each core; Supplementary Table S2) were determined at the French Research Institute for Exploitation of the Sea by wavelength dispersive $x$-ray fluorescence (Bruker S8 Tiger) analysis of fused beads. The bedrock samples were selected from an archive of Svalbard bedrocks that were collected during field campaigns led by the Korea Polar Research Institute from 2013 to 2015 in the Isfjorden and central Spitsbergen areas. We chose samples representing the bedrocks (both age and lithology) in the catchment area of Dicksonfjorden (Supplementary Table S3).

\section{Results}

\section{Lithology and physical properties}

The sediments in the analysed cores are primarily composed of massive reddish-brown mud or sandy mud (Fig. 2, Supplementary Fig. S1). Clasts occur in varying amounts ranging from scattered single clasts to up to 10-cm-thick clast-rich intervals (Fig. 2). Deformation structures, as well as uneven and sharp boundaries, are not observed in both cores.

The JM core is divided into three units based on the varying amounts of clasts (Fig. 2): Unit JM-I (below 192 $\mathrm{cm})$ is composed of mud with scattered clasts; Unit JM-II (192-92 cm) contains massive mud with five $>5$-cm-thick intervals with sand and clasts larger than $2 \mathrm{~mm}$; and Unit JM-III $(92-0 \mathrm{~cm})$ is composed of massive mud with infrequent clasts. 


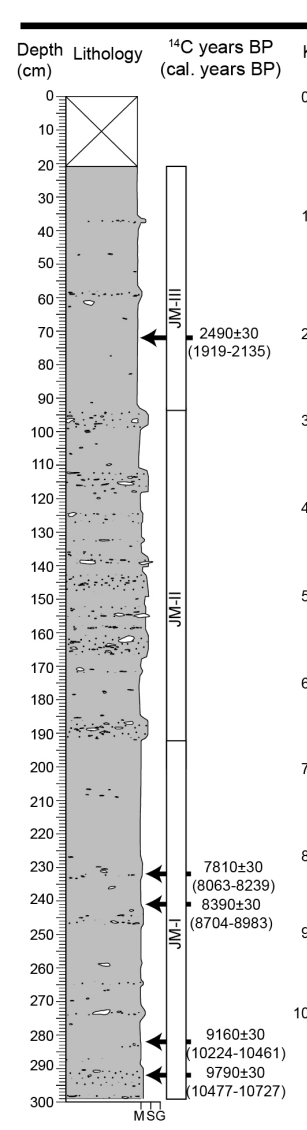

JM05-046-GC

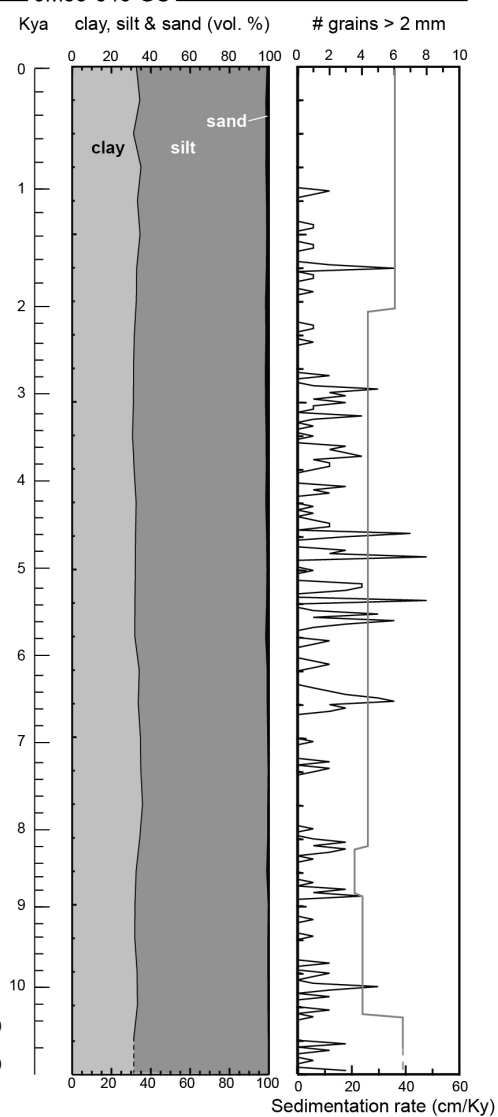

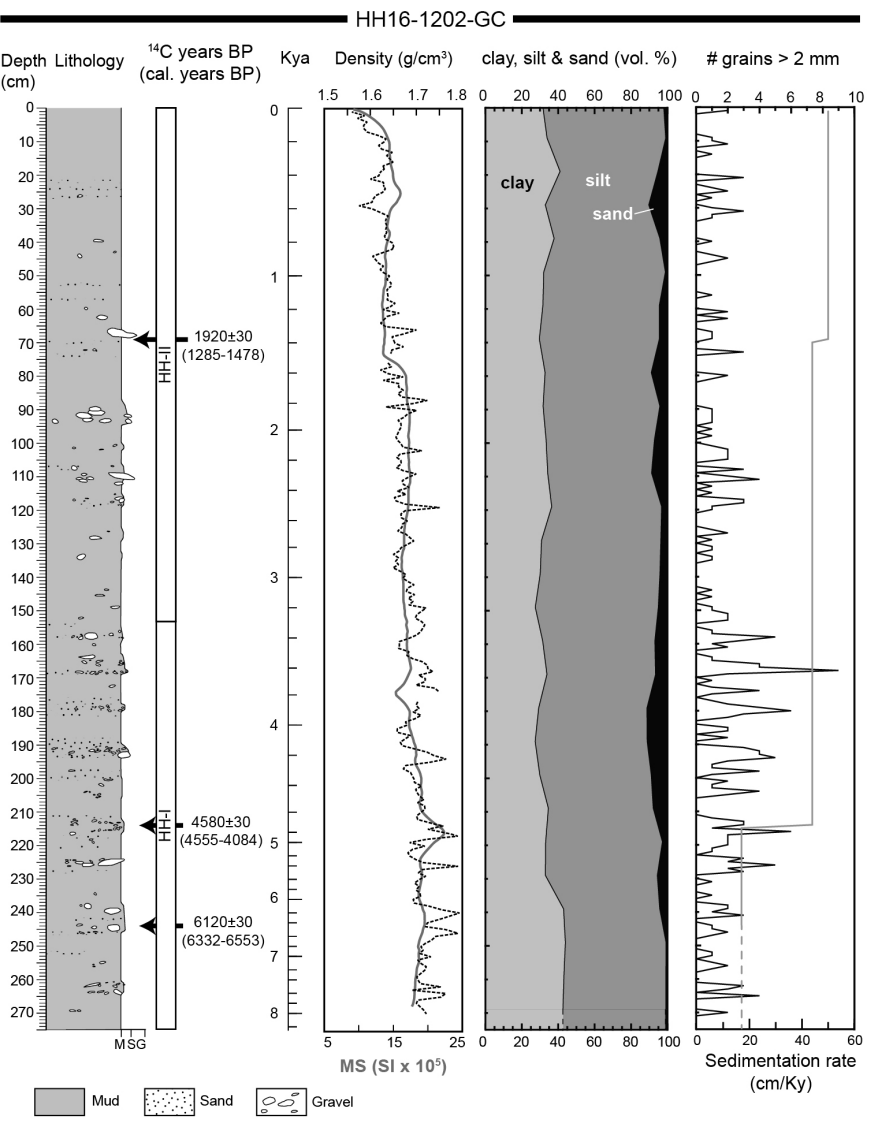

Fig. 2 Lithological logs, chronologies, grain-size distributions and numbers of grains >2 mm, as well as logs of physical properties (HH16-1202-GC only).

The $\mathrm{HH}$ core is divided into two units: Unit HH-I (below $153 \mathrm{~cm}$ ) is composed of massive mud with larger amounts of sand and clasts than Unit HH-II $(153-0 \mathrm{~cm})$. Wet-bulk density and magnetic susceptibility decrease from the bottom to the top of the core. However, peaks within these properties typically correlate with layers of coarser sediments (Fig. 2).

\section{Geochronology and sedimentation rates}

Assuming linear sedimentation rates, the age models yield basal ages of ca. 10.8 and 8.2 Kya in the JM and $\mathrm{HH}$ cores, respectively (Fig. 2). The mean sedimentation rate in the $\mathrm{JM}$ core is $28 \mathrm{~cm} / \mathrm{Ky}$. The highest rate $(39 \mathrm{~cm} / \mathrm{Ky})$ occurs close to the base $(10.8-10.3$ Kya; $292-282 \mathrm{~cm}$ ). After decreasing to the lowest rate $(21 \mathrm{~cm} / \mathrm{Ky})$ between 8.8 and 8.2 Kya $(246-232 \mathrm{~cm})$, the rates increase again to $36 \mathrm{~cm} / \mathrm{Ky}$ in the uppermost part of the core. The mean sedimentation rate in the $\mathrm{HH}$ core is $33 \mathrm{~cm} / \mathrm{Ky}$. The rates increase upcore from 17 $\mathrm{cm} / \mathrm{Ky}(8.2-4.7 \mathrm{Kya} ; 244-214 \mathrm{~cm})$ to $50 \mathrm{~cm} / \mathrm{Ky}(1.4-0$ Kya; 69-0 cm; Fig. 2).

\section{Granulometry and clasts}

The granulometry of the sediments in Dicksonfjorden is dominated by silt (61-68\% in JM; $53-67 \%$ in $\mathrm{HH}$ ) and clay (31-36\% in JM; $27-44 \%$ in HH; Fig. 2). The amount of the sand fraction remains below $2 \%$ in the JM core. However, its percentage increases upcore. In the $\mathrm{HH}$ core, the sand fraction accounts for up to $12 \%$. While there are short intervals without any clasts, intervals with high clast contents (up to $8 / \mathrm{cm}$ ) occur between 6.8 and 2.8 Kya (195 and $90 \mathrm{~cm}$ ) of the JM core (Fig. 2). Similarly, in addition to the low $(<3 / \mathrm{cm})$ but continuous occurrences of clasts in the $\mathrm{HH}$ core, sediment from 5.6 to $3.2 \mathrm{Kya}$ $(230-160 \mathrm{~cm})$ is characterized by multiple clast-rich (up to $9 / \mathrm{cm}$ ) intervals (Fig. 2).

The clast fluxes for the JM core range between 0 and 11 grains $/ \mathrm{cm}^{2} \cdot \mathrm{Ky}$ in the lowermost part of the core $(6.8-$ 10.8 Kya; 195-299 cm) (Fig. 3a). Higher and more continuous clast fluxes from 5 to 19 grains $/ \mathrm{cm}^{2} \cdot \mathrm{Ky}$ occurred between 2.8 and 6.8 Kya $(90-195 \mathrm{~cm})$. From 2.8 Kya $(90$ $\mathrm{cm}$ ), the fluxes were lower and discontinuous (0-6 grains/ $\left.\mathrm{cm}^{2} \cdot \mathrm{Ky}\right)$ compared to the underlying interval, except for a peak (19 grains $/ \mathrm{cm}^{2} \cdot \mathrm{Ky}$ ) around $1.7 \mathrm{Kya}(60 \mathrm{~cm})$. In the 


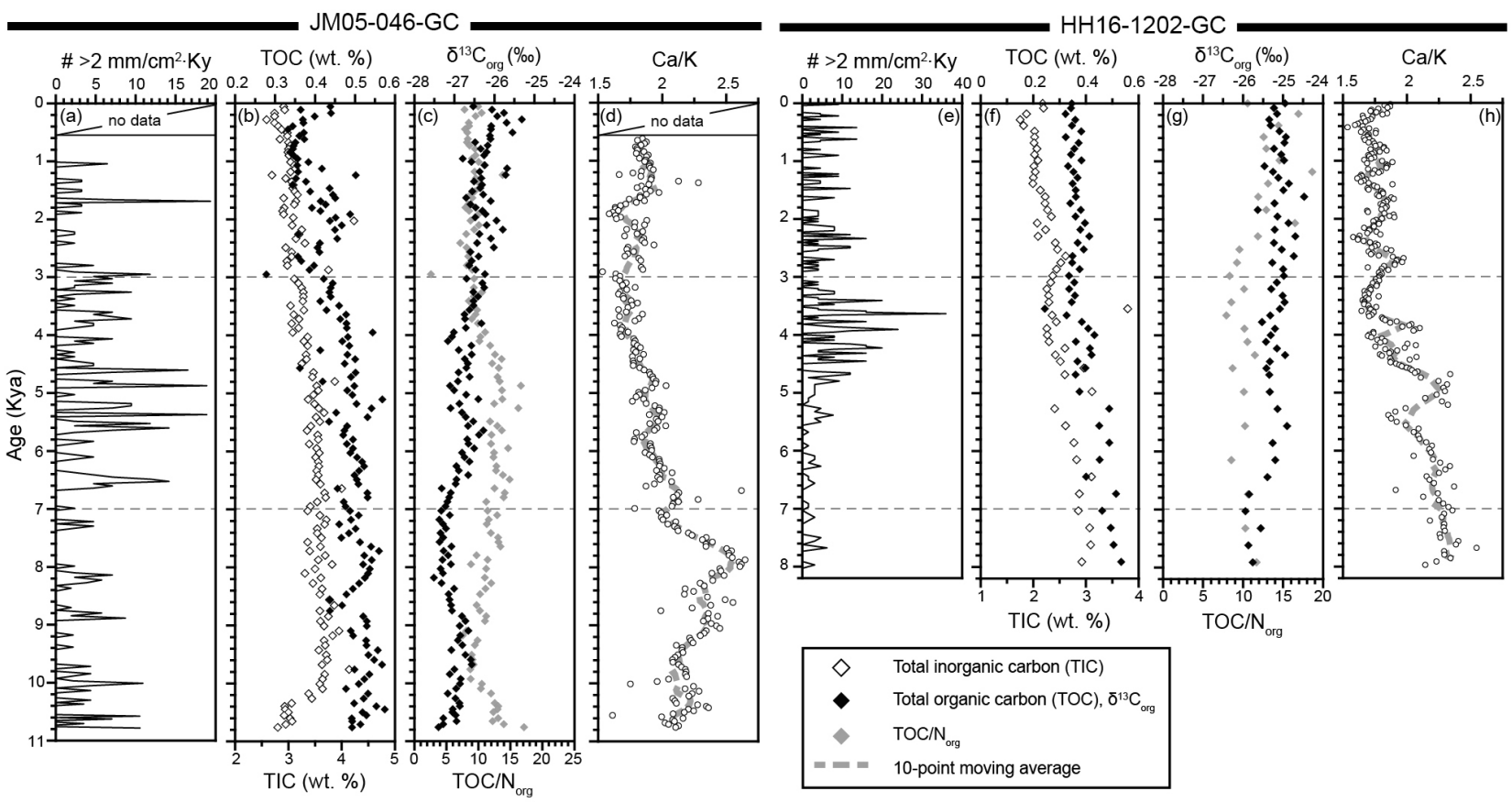

Fig. 3 Calculated clast (>2 mm) fluxes, concentrations of TIC and TOC, $\delta^{13} \mathrm{C}_{\text {org }}$ TOC/N org and Ca/K ratios, in (a-d) JM05-046-GC and (e-h) HH16-1202-GC.

$\mathrm{HH}$ core, clast fluxes remained low prior to ca. $5.6 \mathrm{Kya}$ $\left(230 \mathrm{~cm}\right.$; maximum 5 grains $/ \mathrm{cm}^{2} \cdot \mathrm{Ky}$; Fig. 3e). However, high fluxes with a peak of 34 grains $/ \mathrm{cm}^{2} \cdot \mathrm{Ky}$ occurred between $5.6 \mathrm{Kya}(230 \mathrm{~cm})$ and $3.2 \mathrm{Kya}(160 \mathrm{~cm})$. After $3.2 \mathrm{Kya}$, clast fluxes decreased to $0-16$ grains $/ \mathrm{cm}^{2} \cdot \mathrm{Ky}$.

\section{TIC, TOC, TOC/N $N_{\text {org }}$ and $\delta^{13} C_{\text {org }}$}

The levels of TIC range between 2.5 and $4.2 \%$ in the JM core and 1.8 and $3.8 \%$ in the HH core (Fig. $3 \mathrm{~b}, \mathrm{f}$ ). These values are equivalent to $21-35 \%$ and $15-32 \%$ of $\mathrm{CaCO}_{3^{\prime}}$ respectively. In the JM core, an abrupt increase in TIC contents occurs at about 10.3 Kya $(280 \mathrm{~cm})$, followed by a gradual decrease throughout the core. An upcore decreasing trend is consistently observed in the $\mathrm{HH}$ core. However, a marked increase similar to the increase of TIC in the basal JM sediment is absent (Fig. 3b, f). Both the $\mathrm{JM}$ and $\mathrm{HH}$ sediments contain little organic carbon $(<0.6 \%)$. Similar to the TIC levels, the TOC contents decrease upward in both cores. The variations in TIC and TOC levels lack any strong correlation in the JM $(R=$ $0.21)$ and $\mathrm{HH}(R=0.36)$ cores.

Strong positive or negative excursions in the carbon isotope values of organic carbon are rare in both cores. In the JM core, $\delta^{13} \mathrm{C}_{\text {org }}$ ranges between -27.4 and $-25.4 \%$ (Fig. 3c). The interval between ca. 9 and 6.5 Kya $(250-190 \mathrm{~cm})$ is marked by a slightly negative shift (ca. $0.7 \%$ ) in $\delta^{13} \mathrm{C}_{\text {org }}$. The ratio of TOC/ $\mathrm{N}_{\text {org }}$ varies between 8 and 20 , with the lowermost ratios occurring between 10 and 9 Kya $(272-250 \mathrm{~cm})$ and during the last $3 \mathrm{Ky}$ (ca. $98 \mathrm{~cm})$. The highest ratios are found between ca. 9 and 4 Kya $(248-122 \mathrm{~cm})$. There is a negative correlation between TOC and $\delta^{13} \mathrm{C}_{\text {org }}$ of the JM sediment $(R=-0.56)$.

In the $\mathrm{HH}$ core, $\delta^{13} \mathrm{C}_{\text {org }}$ remains low prior to ca. $6.3 \mathrm{Kya}$, where it increases by about $1 \%$. Small-scale variations of $\delta^{13} \mathrm{C}_{\text {org }}$ between -25.6 and $-24.5 \%$ occur towards the core top (Fig. $3 \mathrm{~g}$ ). Similar to the JM record, TOC/N ratios range between 8 and 18. The last ca. 2 Ky display higher values $(>12)$ than below. The TOC and $\delta^{13} \mathrm{C}_{\text {org }}$ of the $\mathrm{HH}$ sediment also exhibit a strong negative correlation $(R=-0.62)$

\section{Elemental geochemistry}

XRF core scanning reveals upcore decreasing $\mathrm{Ca} / \mathrm{K}$ ratios in both cores (Fig. 3d, h). In the lower part of the JM core, the ratios progressively increase to an overall maximum at ca. 8 Kya $(277 \mathrm{~cm})$, followed by a rapid decrease to a $\mathrm{Ca} / \mathrm{K}$ ratio similar to that at the base. The ratios gradually decrease upcore to ca. $3.8 \mathrm{Kya}(118 \mathrm{~cm})$, from where they fluctuate without clear trends. The base of the HH record exhibits the highest $\mathrm{Ca} / \mathrm{K}$ ratios, followed by a progressively negative trend up to ca. 3.6 Kya $(167 \mathrm{~cm})$. From there, the ratios stabilize, except for some minor variations towards the core top.

Ratios of $\mathrm{K}_{2} \mathrm{O} / \mathrm{CaO}$ and $\mathrm{Fe}_{2} \mathrm{O}_{3} / \mathrm{TiO}_{2}$ of the selected core sediment samples are plotted together with the four bedrocks found in the Isfjorden system: Permian 
mudstone, Carboniferous siltstone, Carboniferous calcareous shale and Devonian sandstone (Fig. 4). The Permian mudstone and Carboniferous calcareous shale exhibit the lowest $\mathrm{K}_{2} \mathrm{O} / \mathrm{CaO}$ ratios; these are almost two orders of magnitude lower than the ratios in the Carboniferous siltstone and Devonian sandstone. On the contrary, the $\mathrm{Fe}_{2} \mathrm{O} / \mathrm{TiO}_{2}$ ratio is highest in the mudstone and lowest in the calcareous shale, whereas the sandstone and siltstone ratios are located in between these end members. The samples from the sediment cores fall within the ranges of the bedrocks (Fig. 4).

\section{Discussion}

\section{Depositional environments}

JM-I (lower mud with low clast content, ca. 11-7 Kya). The lowermost unit (JM-I) is characterized by less frequent clast- and sand-rich intervals compared to the upper units (Fig. 2). The occurrence of clasts indicates that deposition took place in a glacimarine setting. We assume that the energy of bottom currents in Dicksonfjorden is low on account of the shallow sill preventing a strong tidal influence on the deeper parts of the fjords (see Forwick et al. 2010). Therefore, we propose that the clasts were deposited from ice rafting. Although the massive muddy matrix and minor changes in sedimentation rates suggest relatively stable depositional conditions, variations in clast fluxes reflect a variable intensity of ice rafting (Fig. 3a).

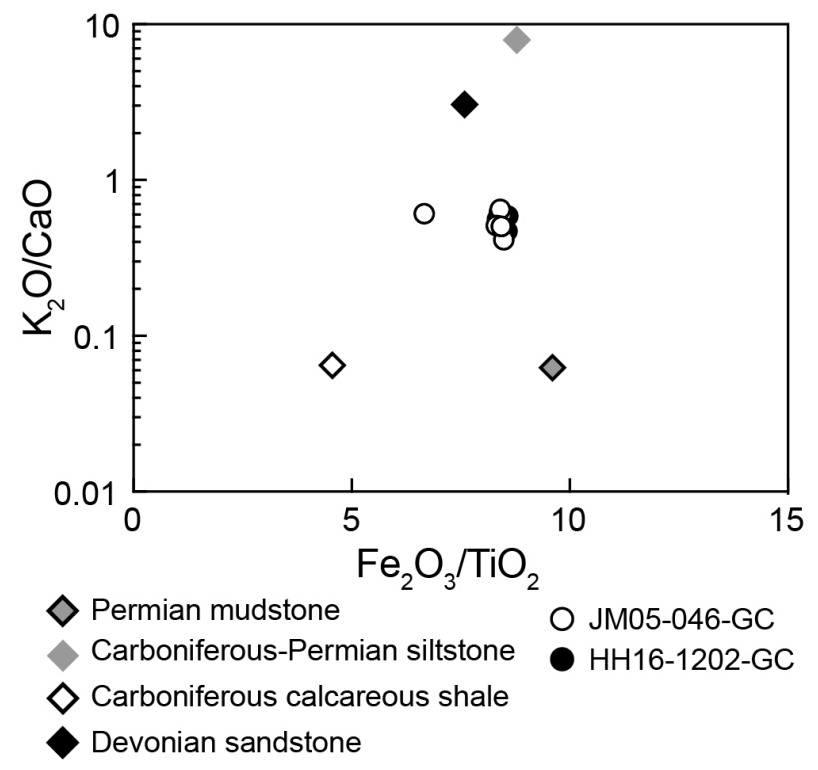

Fig. $4 \mathrm{~K} 2 \mathrm{O} / \mathrm{CaO}$ and $\mathrm{Fe}_{2} \mathrm{O}_{3} / \mathrm{TiO}_{2}$ ratios of selected sediment samples and bedrocks.
Unit JM-I correlates to the sediment Unit I-Ml in central Isfjorden (Forwick \& Vorren 2009) and Unit 943-C in Billefjorden (Baeten et al. 2010). It was most probably deposited after the termination of the deglaciation of Dicksonfjorden. Like the correlated units of Forwick $\delta$ Vorren (2009) and Baeten et al. (2010), this unit was deposited during a period of reduced ice rafting under relatively warm climatic conditions during the early Holocene. As the warmth presumably prevented extensive sea-ice formation, we assume that most clasts were deposited from icebergs (see Forwick \& Vorren 2009; Baeten et al. 2010). This may suggest that Battyebreen, which had retreated markedly during the last deglaciation, was still a tidewater glacier at least during the early phase of this interval. The high amount of grains larger than $2 \mathrm{~mm}$ shortly after ca. $9 \mathrm{Kya}$, on the contrary, can be related to the regional cooling in Svalbard (e.g., Svendsen \& Mangerud 1997; Hald et al. 2004; Forwick \& Vorren 2009; Rasmussen et al. 2012; Mangerud \& Svendsen 2018) that favoured sea-ice rafting. It can be explained by (1) enhanced ice rafting as observed in van Mijenfjorden (Hald et al. 2004) and central Isfjorden (Forwick \& Vorren 2009) starting from 8.8 and 9.0 Kya, respectively, and/or (2) the progradation of the deltas closer to the JM site, as the region underwent glacio-isostatic rebound resulting in ca. $60 \mathrm{~m}$ fall in relative sea level in the neighbouring Billefjorden (Salvigsen 1984; Forman et al. 2004). As the distance from the deltas decreased, coarse delta sediments entrained in sea ice might have been more readily transported to the core site.

JM-II and HH-I (middle mud with high clast content, ca. 7-3 Kya). The units JM-II and HH-I are characterized by relatively abundant coarser intervals (Fig. 2). They can be correlated to Unit 943-D in Billefjorden (Baeten et al. 2010). Periods of increased ice rafting are inferred from the high clast fluxes in these units (Fig. 3a, e). The generally higher sand contents in the $\mathrm{HH}$ core compared to the JM core (Fig. 2) can be related to (1) more intensive seaice formation at and close to the fjord head compared to the fjord mouth, leading to enhanced sea-ice rafting in the inner fjord and/or (2) the progradation of the river systems of Dicksonelva and Nathorstelva (Fig. 1b) during the period of relatively stable sea level (Forman et al. 2004), potentially triggering the deposition by turbidity flows.

JM-III and HH-II (upper mud with low clast content, ca. 3 Kya-present). The units JM-III and HH-II are characterized by lower clast fluxes than the underlying sediments (Fig. 3a, e). These units are correlated to the units 943-E in Billefjorden (Baeten et al. 2010) and I-Mu in central Isfjorden (Forwick \& Vorren 2009). We suggest that, like units 943-E and I-Mu, JM-III and HH-II reflect reduced ice rafting due to the presence of more shorefast and/or multi-annual sea ice, preventing ice flows from 
drifting in the fjord (e.g., Forwick \& Vorren 2009; Baeten et al. 2010). However, generally higher sand and clast contents in the Unit HH-II compared to JM-III again indicate that somewhat more ice rafting occurred in the inner fjord compared to the outer fjord and/or that coarser sediments could be derived from the prograding adjacent river-delta systems.

\section{Additional depositional processes}

It should also be considered that in a fjord system hosting a land-terminating glacier, tidal flats are known to act as a transitional sediment trap for the riverborne sediment, prior to the final deposition in the fjord via turbidity flow, tidal pumping and settling, and winter ice cover scouring (e.g., Zajączkowski \& Włodarska-Kowalczuk 2007; Zajączkowski 2008). Such processes could also occur in the tidal flats developed at the mouths of Dicksonelva and Nathorstelva. Turbidity flows triggered by high sedimentation rates can lead to delta lip collapse during a spring season (Clare et al. 2016) and transport coarse sediment to the fjord (Holthuis 2018). While the main sedimentation modes during the Holocene are still interpreted as (1) background sedimentation in the form of suspension settling from the water column and (2) sea-ice rafting of coarse grains in Dicksonfjorden (Holthuis 2018), delta-derived sandy sediment deposition by turbidity flows occurring on shorter time scales cannot be ignored. However, the absence of structures characteristic for turbidites (e.g., lamination or convoluted bedding; Shanmugam 1997) and the dominance of mud (Fig. 2) might reflect that-if turbidity flows occurred-they were rather low-energy turbidity flows that were too weak to generate structures comparable to those observed in other Arctic fjord systems (e.g., Cowan et al. 1999; Zajaczkowski \& Wlodarska-Kowalczuk 2007).

\section{Sediment sources}

The overall upcore decreasing $\mathrm{Ca} / \mathrm{K}$ ratios in the studied cores are assumed to reflect decreasing proportions of Ca-bearing (e.g., calcium carbonate and Ca-plagioclase) and/or increasing K-bearing (e.g., K-feldspar and phyllosilicate) minerals. As the TIC variations also show an overall negative trend similar to those of $\mathrm{Ca} / \mathrm{K}$ in both cores (Fig. 3), the primary Ca carrier rather seems to be $\mathrm{CaCO}_{3}$. The observed variations can result from (1) decreasing detrital carbonate input from the carbonate-bearing bedrocks in the outer fjord in combination with increasing sediment supply from the siliciclastic deposits (i.e., Devonian Old Red) surrounding the inner fjord and the catchment of Dicksonelva, and (2) dilution of biogenic carbonate deposition due to increasing rates of siliciclastic sedimentation. To further evaluate sources of the siliciclastic detritus, we additionally use the ratios of $\mathrm{Fe}_{2} \mathrm{O}_{3} / \mathrm{TiO}_{2}$ because these elements primarily reside in non-carbonate minerals. As shown in Fig. 4, the sediment samples appear to be a mixture of the bedrocks with different compositions, suggesting that the detrital sediment supply occurs both from the upper Palaeozoic deposits along the fjord sides and from the Devonian sandstone and siltstone.

The lack of a strong positive correlation between TIC and TOC suggests that carbonate and organic carbon in the sediments derived both from in situ biogenic production and from other sources. To discern the sources of organic carbon, we compared $\delta^{13} \mathrm{C}_{\text {org }}$ and/or TOC/ $\mathrm{N}_{\text {org }}$ ratios of sediments with possible sources of organic carbon. We adopted the values of fresh organic carbon with various origins, including marine and freshwater particulate organic carbon, algae, bacteria, C3 plants and modern terrestrial OM (Lamb et al. 2006 and references therein), as well as modern Svalbard marine OM (Winkelmann \& Knies 2005). In addition, we compiled the compositions of old OM in the Palaeozoic and Mesozoic sedimentary rocks in Svalbard (Fig. 5; Ekart et al. 1999; Mørk et al. 1999; Galfetti et al. 2007; Grasby et al. 2015). Based on their TOC/ $\mathrm{N}_{\text {org }}$ ratios and $\delta^{13} \mathrm{C}_{\text {org }}$ values, the sediment seems to be derived mainly from sources on land-modern terrestrial OM, freshwater particulates or bedrock (Fig. 5). Although biomarker analysis is required to verify the type of OM, our result indicates that a large proportion of both carbonate and organic carbon

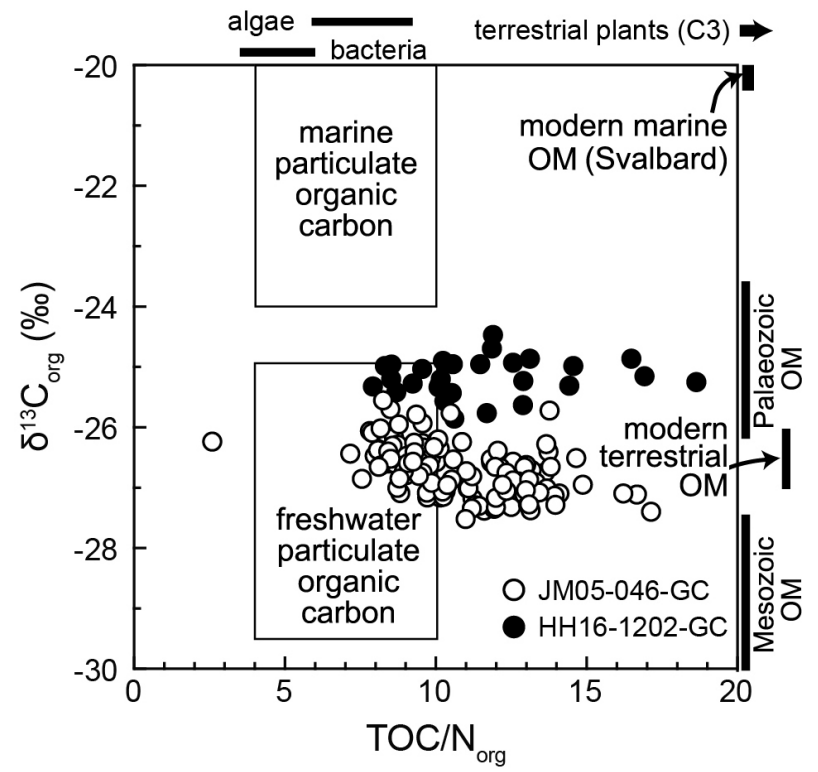

Fig. $5 \mathrm{TOC} / \mathrm{N}_{\text {org }}$ and $\delta^{13} \mathrm{C}_{\text {org }}$ of $\mathrm{JM}$ and $\mathrm{HH}$ samples, as well as of potential sources of OM in Dicksonfjorden. 
is allochthonous. The negative correlation between TOC and $\delta^{13} \mathrm{C}_{\text {org }}$ in the studied sediments further supports substantial organic carbon supply from terrestrial sources characterized by lighter isotopic values.

Some of the observed variations can be attributed to biogenic production; for instance, the early Holocene (ca. $10 \mathrm{Kya}$ ) decrease of TOC $/ \mathrm{N}_{\text {org }}$ in accordance with $\delta^{13} \mathrm{C}_{\text {org }}$ values shifting towards heavier values than the lowermost part in JM (Fig. 3c) may reflect enhanced primary production due to the relatively warm climate and heat and nutrient flux from the strong inflow of Atlantic Water (e.g., Hald et al. 2004; Forwick \& Vorren 2009; Rasmussen et al. 2012). The greater depth of the sill in the fjord mouth during the early Holocene (see Forman et al. 2004) could also facilitate the connection between the relatively fresh fjord water and more saline, nutrient-rich Atlantic Water. In addition, the formation of seasonal sea ice can promote export production of OM during the spring sea-ice break-up (e.g., Fortier et al. 2002). Similarly, the lower TOC $/ \mathrm{N}_{\text {org }}$ ratios and positive shift in $\delta^{13} \mathrm{C}_{\text {org }}$ after ca. 4.2 Kya in the JM core suggest an increasing proportion of marine OM produced by primary production that is characterized by low $\mathrm{C} / \mathrm{N}$ ratio and heavy $\delta^{13} \mathrm{C}_{\text {org }}$ (Meyers 1994; Knies \& Martinez 2009).

\section{Holocene environmental changes in Dicksonfjorden}

Early-middle Holocene (ca. 11-7 Kya). Plumes from glacifluvial rivers draining terrestrial glaciers and turbid meltwater plumes emanating from tidewater glaciers were presumably the main sources of fine-grained sediments (Fig. 6a, b). The high $\mathrm{Ca} / \mathrm{K}$ ratios during the early Holocene in the JM core (Fig. 3d) are inferred to reflect (1) enhanced sediment supply from the fjord sides during the early Holocene and (2) enhanced biogenic carbonate production facilitated during the relatively warm conditions as observed elsewhere in western Spitsbergen, eastern Fram Strait and western Barents Sea (Fig. 7; Sarnthein et al. 2003; Hald et al. 2004; Forwick \& Vorren 2009; Baeten et al. 2010; Rasmussen et al. 2012; Werner et al. 2016; Mangerud \& Svendsen 2018; van der Bilt et al. 2018).

Clasts can be deposited by both icebergs calving off the fronts of tidewater glaciers and sea ice. While the extent of tidewater glaciers was reduced to a minimum during the early Holocene, the formation of sea ice was also suppressed by warm climatic and oceanographic conditions (e.g., Hald et al. 2004; Forwick \& Vorren 2009; Rasmussen et al. 2012). It is therefore reasonable to assume that the clasts were primarily transported by icebergs from Battyebreen, which must have been still a tidewater glacier during the early part of the interval (Fig. 6a). Once glacial
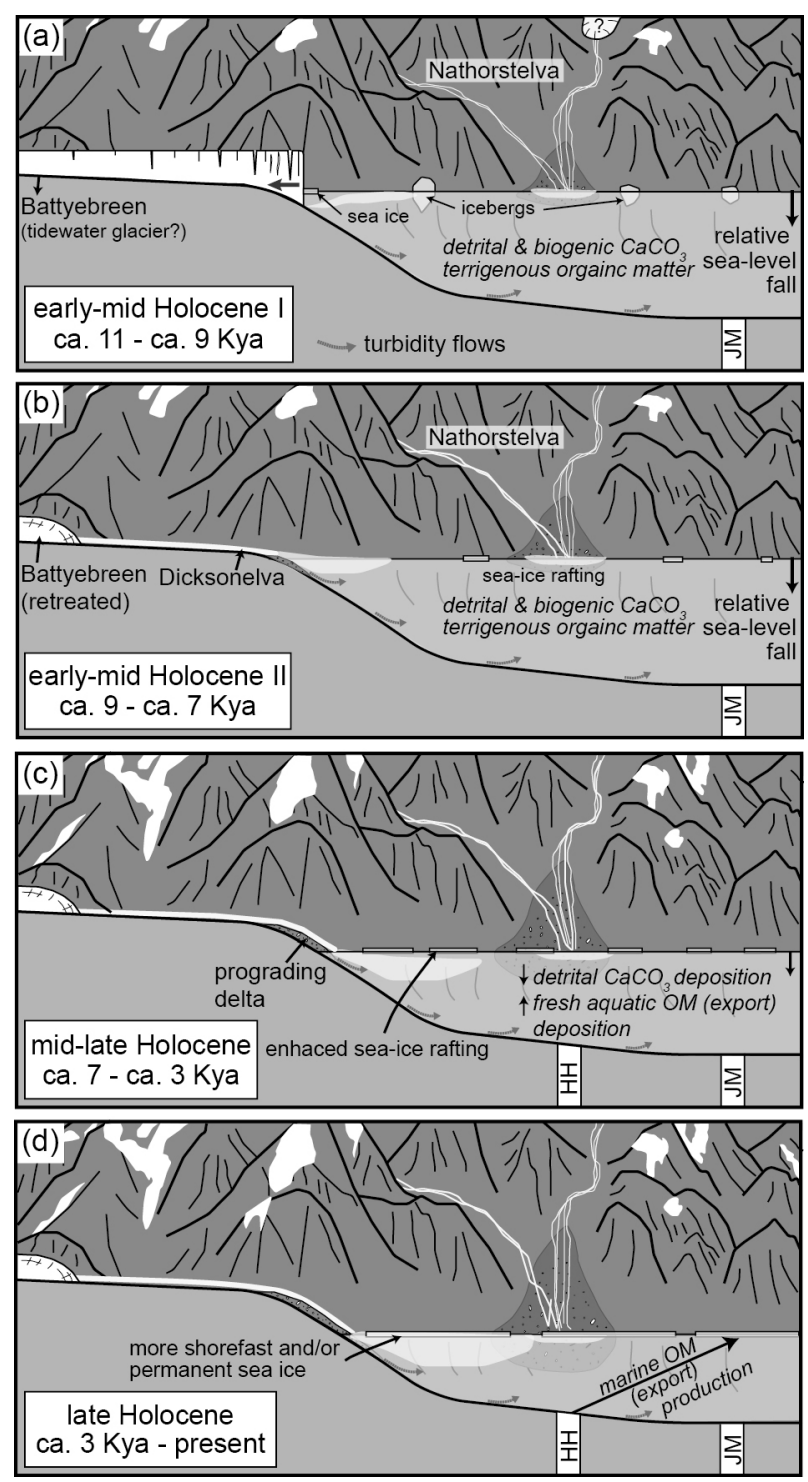

Fig. 6 Conceptual model summarizing the environmental conditions affecting depositional processes in Dicksonfjorden during the past ca. $11 \mathrm{Kya}$.

retreat and regional uplift made Battyebreen a land-terminating glacier, ice rafting occurred by sea ice (Fig. 6b).

Marine and freshwater $\mathrm{OM}$ with low $\mathrm{C} / \mathrm{N}$ ratios, as well as biogenic carbonate, were produced between 10 and 8 Kya (Fig. 3b, c). The decoupling of TOC and TIC during the early Holocene (e.g., ca. 10.3 Kya), however, may reflect considerable detrital carbonate input.

Middle-late Holocene (ca. 7-3 Kya). Enhanced seaice rafting during this period (Fig. 7a) can be related to the decreasing insolation (Fig. 7a; Berger \& Loutre 1991) resulting in a regional cooling in the Svalbard and the surrounding Arctic Atlantic (Fig. 7b-e; Sarnthein et al. 2003; 

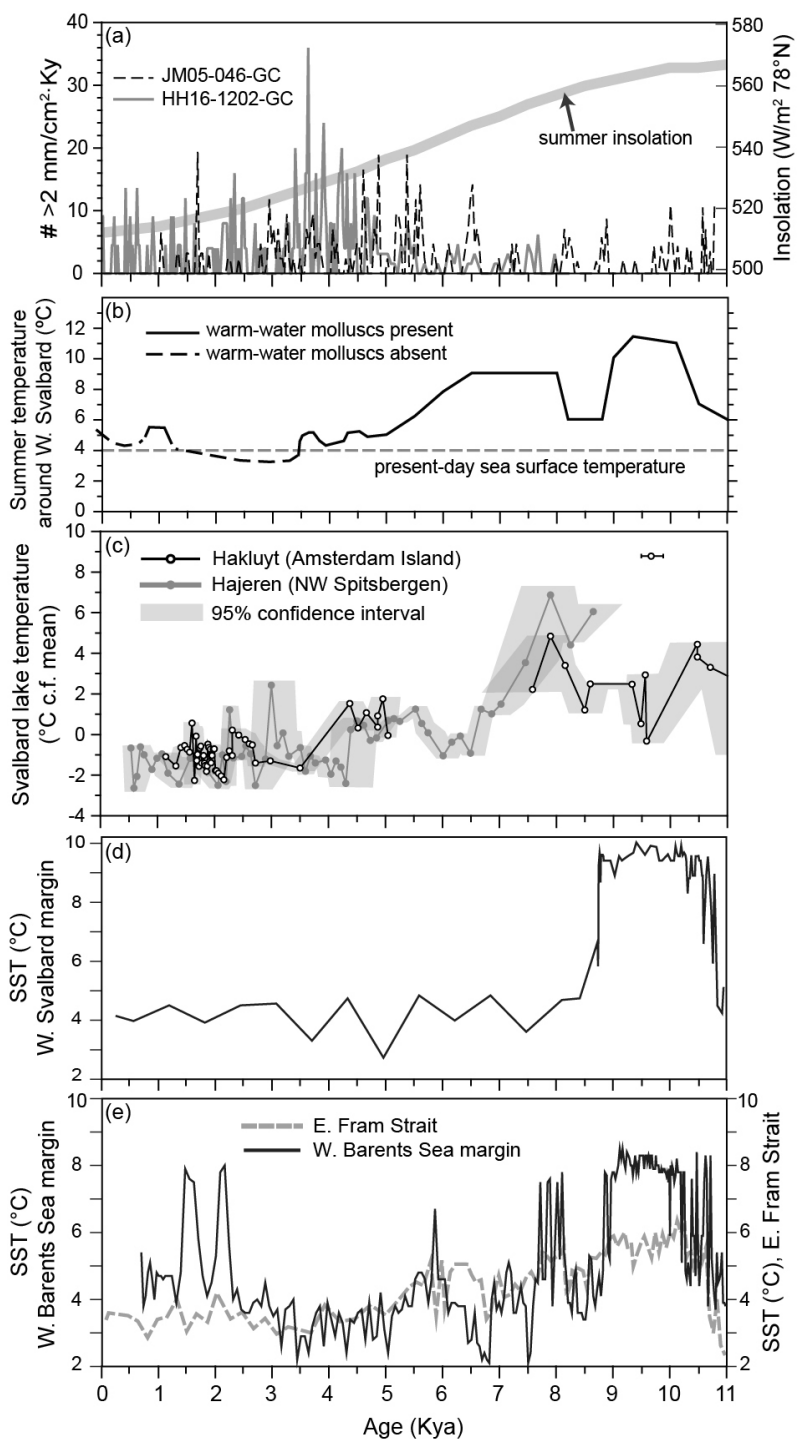

Fig. 7 (a) Comparison of results of this study with June insolation at $78^{\circ} \mathrm{N}$ (Berger \& Loutre 1991); (b) August temperatures of western Spitsbergen obtained from the occurrences of warm-water molluscs (Mangerud \& Svendsen 2018); (c) lake-water temperatures for Hakluytvatnet and Hajeren in north-western Svalbard expressed as relative to mean Holocene values (van der Bilt et al. 2018); (d) sea-surface temperatures off western Svalbard (Hald et al. 2004); (e) and sea-surface temperatures in the western Barents Sea (Sarnthein et al. 2003) and the eastern Fram Strait (Werner et al. 2016).

Hald et al. 2004; Ślubowska et al. 2005; Hald et al. 2007; Werner et al. 2016; Mangerud \& Svendsen 2018; van der Bilt et al. 2018). Our observations of intensified sea-ice rafting from ca. 7 Kya (Figs. 6c, 7a) support earlier studies of the Isfjorden area that suggest asynchronous glacier growth from ca. 9 Kya (Svendsen \& Mangerud 1997;
Forwick \& Vorren 2007, 2009; Baeten et al. 2010; Forwick et al. 2010; Rasmussen et al. 2012). The discrepancy in the inferred timing of glacier growth and/or enhanced ice rafting can be attributed to local differences in temperature and/or precipitation in central Spitsbergen.

The source of organic carbon deposited in the study area was unchanged as reflected in the relatively stable $\mathrm{TOC} / \mathrm{N}_{\text {org }}$ and $\delta^{13} \mathrm{C}_{\text {org }}$ values. Considering the gradually decreasing $\mathrm{Ca} / \mathrm{K}$ ratios, the relative proportion of detritus transported from the Old Red Sandstone likely increased, in comparison with the sediment flux from the carbonate-bearing rocks in the fjord sides, because of the progradation of Dicksonelva and Nathorstelva towards the core sites (Fig. 6c). The $\delta^{13} \mathrm{C}_{\text {org }}$ values heavier than those of the earlier interval can be related to an increased fraction of fresh OM produced in surface waters (Fig. 5). This was probably influenced by enhanced (seasonal) sea-ice formation, which facilitated the export of algal material and bloom products from the photic zone to the seafloor (see Fortier et al. 2002).

Late Holocene (ca. 3 Kya-present). The overall lower clast fluxes (Fig. 3a, e) reflect reduced sea-ice rafting (Fig. 7a), most probably due to a relatively cold climate and reduced inflow of Atlantic Water to Dicksonfjorden. Multiple studies reveal cooler conditions in and around Svalbard (Fig. 7b-d; e.g., Svendsen 8 Mangerud 1997; Hald et al. 2004; Rasmussen et al. 2007; Ślubowska-Woldengen et al. 2007; Forwick $\&$ Vorren 2009; Rasmussen et al. 2012; Mangerud \& Svendsen 2018; van der Bilt et al. 2018), eastern Fram Strait (Fig. 7e; Werner et al. 2016) and western Barents Sea (Fig. 7e; Sarnthein et al. 2003) during the late Holocene. As the period is characterized by the lowest inflow of Atlantic Water to Isfjorden, and presumably enhanced shorefast sea-ice formation and/ or more permanent sea-ice cover in central Isfjorden and some eastern branches (e.g., Forwick \& Vorren 2009; Baeten et al. 2010; Forwick et al. 2010; Rasmussen et al. 2012), we suggest that similar conditions prevailed in Dicksonfjorden (Fig. 6d). In addition, the sill at the mouth of Dicksonfjorden reached its shallowest water depth during this time as a result of the ongoing isostatic rebound (see Forman et al. 2004), presumably further isolating the area from the already reduced influence of Atlantic Water. The clast fluxes were higher in the $\mathrm{HH}$ core in comparison with the JM core; the delta progradation during the sealevel lowstand allowed more coarse sediment grains to be transported by sea ice and turbidity flows to the HH site.

Heavier $\delta^{13} \mathrm{C}_{\text {org }}$ and lower TOC $/ \mathrm{N}_{\text {org }}$ values in the JM core compared to the $\mathrm{HH}$ core are characteristic of the greater proportion of marine OM in the sediment. Albeit greatly reduced, the episodic inflow of Atlantic Water after ca. 2 Kya (see Rasmussen et al. 2012; Jernas et al. 2013) might 
facilitate primary production in the JM site closer to the fjord mouth. On the contrary, the increasing TOC $/ \mathrm{N}_{\text {org }}$ ratios point towards a larger amount of terrestrial $\mathrm{OM}$ in the $\mathrm{HH}$ core. This can be explained as a consequence of (1) suppressed primary production in the photic zone as the area is subject to the higher flux of turbid water emanating from Dicksonelva and Nathorstelva and/or (2) enhanced terrigenous sediment input owing to the progradation of the delta systems in its proximity. In the turbid water column, the limited light availability favours the development of heterotrophic organisms and thereby weakens export production (e.g., Keck et al. 1999; Zajączkowski et al. 2010).

\section{Conclusions}

We studied the lithological, physical and chemical properties of the Holocene sediments in Dicksonfjorden, a fjord currently unaffected by tidewater glaciers, to reconstruct the environmental development in the fjord, including shifts in sources of detrital sediment and OM, fluctuations in ice rafting, and falling relative sea level in response to post-glacial isostatic rebound. Sediment supply occurred primarily from suspension settling and ice rafting, with minor sediment reworking by turbidity flows. Carbon isotope composition and $\mathrm{TOC} / \mathrm{N}_{\text {org }}$ ratios suggest that terrigenous OM, both old and fresh (terrestrial and aquatic), predominates over small proportions of OM produced in situ. We distinguished three periods with characteristic environmental conditions: the early-mid Holocene (ca. 11-7 Kya), mid-late Holocene (ca. 7-3 Kya) and late Holocene (ca. 3 Kya-present).

Occasional ice rafting, both from icebergs and sea ice, occurred during the early-mid Holocene. Iceberg rafting presumably prevailed during the warmest interval prior to $9 \mathrm{Kya}$, when Battyebreen remained a tidewater glacier. However, sea-ice rafting was probably the only ice-rafting process during the later part of this period, once Battyebreen changed to a land-terminating glacier. Enhanced sea-ice rafting occurred during the mid-late Holocene. This can be related to decreasing insolation, leading to regional cooling, as well as reduced heat flux from the weakened inflow of Atlantic Water. Furthermore, the falling sea-level during the early to late Holocene promoted the progradation of stream outlets and delta systems, the predominant source of both fine and coarse sediments, closer to the core sites; it resulted in coarsening of the sediments (i.e., increasing sand contents) and higher clast flux to the inner fjord. Relatively cold climate and reduced inflow of Atlantic Water during the late Holocene led most probably to the formation of shorefast and/or permanent sea ice, suppressing ice rafting. However, episodic inflow of Atlantic
Water likely occurred, facilitating primary production of marine OM in the outer fjord, whereas turbid meltwater delivery inhibited (export) production in the inner part.

Our study reveals that the sediments in Dicksonfjorden, a fjord where sediment supply primarily occurred from rivers during the majority of the Holocene, archive environmental conditions comparable to other Svalbard fjords influenced by tidewater glaciers.

\section{Acknowledgements}

The captains and crews of RV Jan Mayen/Helmer Hanssen and S. Iversen supported the core and data collection during the cruise. The JM05-046-GC core and the bedrock samples were generously provided by K.-C. Yoo and J. Woo. T. Dahl, I. Hald and K. Monsen are thanked for their support during the laboratory work at the Department of Geosciences at UiT. At the Korea Institute of Geoscience and Mineral Resources, G. Kong kindly supported XRF core scanning of the JM core and J. Lim helped the authors with the laser particle size analysis. G. Bayon is thanked for XRF analysis of sediment and rock samples. The authors thank E.J. Byun, B. Lee and J. Lee for their assistance during laboratory work. Constructive comments from two anonymous reviewers and the Subject Editor R. Spielhagen greatly improved this manuscript.

\section{Disclosure statement}

The authors report no conflict of interest.

\section{Funding}

This research was supported by the Basic Core Technology Development Program for the Oceans and the Polar Regions (NRF-2015MlA5A1037243) from the National Research Foundation of Korea funded by the Ministry of Science and ICT.

\section{References}

Baeten N.J., Forwick M., Vogt C. \& Vorren T.O. 2010. Late Weichselian and Holocene sedimentary environments and glacial activity in Billefjorden, Svalbard. In J. Howe et al. (eds.): Fjord systems and archives. Pp. 207-223. London: The Geological Society.

Beierlein L., Salvigsen O., Schöne B.R., Mackensen A. \& Brey T. 2015. The seasonal water temperature cycle in the Arctic Dicksonfjord (Svalbard) during the Holocene Climate Optimum derived from subfossil Arctica islandica shells. The Holocene 25, 1197-1207, https://doi. org/10.1177/0959683615580861. 
Berger A. \& Loutre M.-F. 1991. Insolation values for the climate of the last 10 million years. Quaternary Science Reviews 10, 297-317, https://doi.org/10.1016/0277-3791(91)90033-Q.

Clare M.A., Hughes Clarke J.E., Talling P.J., Cartigny M.J.B. \& Pratomo D.G. 2016. Preconditioning and triggering of offshore slope failures and turbidity currents revealed by most detailed monitoring yet at a fjord-head delta. Earth and Planetary Science Letters 450, 208-220, https://doi. org/10.1016/j.epsl.2016.06.021.

Cottier F.R., Nilsen F., Inall M.E., Gerland S., Tverberg V. \& Svendsen H. 2007. Wintertime warming of an Arctic shelf in response to large-scale atmospheric circulation. Geophysical Research Letters 34, L10607, https://doi. org/10.1029/2007GL029948.

Cowan E.A., Seramur K.C., Cai J. \& Powell R.D. 1999. Cyclic sedimentation produced by fluctuations in meltwater discharge, tides and marine productivity in an Alaskan fjord. Sedimentology 46, 1109-1126, https://doi. org/10.1046/j.1365-3091.1999.00267.x.

Dallmann W. \& Elvevold S. 2015. Bedrock geology. In W. Dallmann (ed.): Geoscience atlas of Svalbard. Norwegian Polar Institute Report Series 148. Pp. 133-173. Tromsø: Norwegian Polar Institute.

Ekart D.D., Cerling T.E., Montanez I.P. \& Tabor N.J. 1999. A 400 million year carbon isotope record of pedogenic carbonate: implications for paleoatmospheric carbon dioxide. American Journal of Science 299, 805-827, https://doi. org/10.2475/ajs.299.10.805.

Elverhøi A., Andersen E.S., Dokken T., Hebbeln D., Spielhagen R., Svendsen J.I., Sørflaten M., Rørnes A., Hald M. \& Forsberg C.F. 1995. The growth and decay of the Late Weichselian ice sheet in western Svalbard and adjacent areas based on provenance studies of marine sediments. Quaternary Research 44, 303-316, https://doi.org/10.1006/ qres.1995.1076.

Farnsworth W.R., Ingólfsson Ó., Noormets R., Allaart L., Alexanderson H., Henriksen M. \& Schomacker A. 2017. Dynamic Holocene glacial history of St. Jonsfjorden, Svalbard. Boreas 46, 585-603, https://doi.org/10.1111/bor.12269.

Forman S.L., Lubinski D.J., Ingólfsson Ó., Zeeberg J.J., Snyder J.A., Siegert M.J. \& Matishov G.G. 2004. A review of postglacial emergence on Svalbard, Franz Josef Land and Novaya Zemlya, northern Eurasia. Quaternary Science Reviews 23, 1391-1434, https://doi.org/10.1016/j. quascirev.2003.12.007.

Fortier M., Fortier L., Michel C. \& Legendre L. 2002. Climatic and biological forcing of the vertical flux of biogenic particles under seasonal Arctic sea ice. Marine Ecology Progress Series 225, 1-16, https://doi.org/10.3354/meps225001.

Forwick M. \& Vorren T.O. 2007. Holocene mass-transport activity and climate in outer Isfjorden, Spitsbergen: marine and subsurface evidence. The Holocene 17, 707-716, https://doi.org/10.1177/0959683607080510.

Forwick M. \& Vorren T.O. 2009. Late Weichselian and Holocene sedimentary environments and ice rafting in Isfjorden, Spitsbergen. Palaeogeography, Palaeoclimatology, Palaeoecology 280, 258-274, https://doi.org/10.1016/j. palaeo.2009.06.026.
Forwick M., Vorren T.O., Hald M., Korsun S., Roh Y., Vogt C. \& Yoo K.-C. 2010. Spatial and temporal influence of glaciers and rivers on the sedimentary environment in Sassenfjorden and Tempelfjorden, Spitsbergen. In J. Howe et al. (eds.): Fjord systems and archives. Pp. 163-193. London: The Geological Society.

Galfetti T., Hochuli P.A., Brayard A., Bucher H., Weissert H. \& Vigran J.O. 2007. Smithian-Spathian boundary event: evidence for global climatic change in the wake of the end-Permian biotic crisis. Geology 35, 291-294, https://doi. org/10.1130/G23117A.1.

Grasby S.E., Beauchamp B., Bond D.P.G., Wignall P., Talavera C., Galloway J.M., Piepjohn K., Reinhardt L. \& Blomeier D. 2015. Progressive environmental deterioration in northwestern Pangea leading to the latest Permian extinction. Geological Society of America Bulletin 127, 1331-1347, https://doi.org/10.1130/B31197.1.

Grobe H. 1987. A simple method for the determination of ice-rafted debris in sediment cores. Polarforschung 57, 123-126.

Hagen J.O., Liestøl O., Roland E. \& Jørgensen T. 1993. Glacier atlas of Svalbard and Jan Mayen. Norway: Norwegian Polar Institute.

Hald M., Andersson C., Ebbesen H., Jansen E., Klitgaard-Kristensen D., Risebrobakken B., Salomonsen G.R., Sarnthein M., Sejrup H.P. \& Telford R.J. 2007. Variations in temperature and extent of Atlantic Water in the northern North Atlantic during the Holocene. Quaternary Science Reviews 26, 3423-3440, https://doi.org/10.1016/j. quascirev.2007.10.005.

Hald M., Ebbesen H., Forwick M., Godtliebsen F., Khomenko L., Korsun S., Olsen L.R. \& Vorren T.O. 2004. Holocene paleoceanography and glacial history of the west Spitsbergen area, Euro-Arctic margin. Quaternary Science Reviews 23, 2075-2088, https://doi.org/10.1016/j.quascirev.2004.08.006.

Holthuis M. 2018. Sedimentation processes in a non-glaciated fjord setting: Dicksonfjorden, Svalbard. Amsterdam: Vrije Universiteit.

Jernas P., Klitgaard Kristensen D., Husum K., Wilson L. \& Koç N. 2013. Palaeoenvironmental changes of the last two millennia on the western and northern Svalbard shelf. Boreas 42, 236-255, https://doi.org/10.1111/j.1502-3885.2012.00293.x.

Keck A., Wiktor J., Hapter R. \& Nilsen R. 1999. Phytoplankton assemblages related to physical gradients in an Arctic, glacier-fed fjord in summer. ICES Journal of Marine Science 56, 203-214, https://doi.org/10.1006/jmsc.1999.0631.

Knies J. \& Martinez P. 2009. Organic matter sedimentation in the western Barents Sea region: terrestrial and marine contribution based on isotopic composition and organic nitrogen content. Norwegian Journal of Geology 89, 79-89.

Kvam M.H. 2018. Deposits and processes on the tide-influenced fjord-head delta in Dicksonfjorden, Svalbard. Tromsø: Dept. of Geosciences, UiT-The Arctic University of Norway.

Lamb A.L., Wilson G.P. \& Leng M.J. 2006. A review of coastal palaeoclimate and relative sea-level reconstructions using $\delta^{13} \mathrm{C}$ and $\mathrm{C} / \mathrm{N}$ ratios in organic material. Earth-Science Reviews 75, 29-57, https://doi.org/10.1016/j. earscirev.2005.10.003. 
Lønne I. \& Nemec W. 2004. High-Arctic fan delta recording deglaciation and environment disequilibrium. Sedimentology 51, 553-589, https://doi.org/10.1111/j.1365-3091. 2004.00636.x.

Mangerud J., Bolstad M., Elgersma A., Helliksen D., Landvik J.Y., Lønne I., Lycke A.K., Salvigsen O., Sandahl T. \& Svendsen J.I. 1992. The last glacial maximum on Spitsbergen, Svalbard. Quaternary Research 38, 1-31, https://doi. org/10.1016/0033-5894(92)90027-G.

Mangerud J. \& Svendsen J.I. 2018. The Holocene Thermal Maximum around Svalbard, Arctic North Atlantic; molluscs show early and exceptional warmth. The Holocene 28, 65-83, https://doi.org/10.1177/0959683617715701.

Meyers P.A. 1994. Preservation of elemental and isotopic source identification of sedimentary organic matter. Chemical Geology 114, 289-302, https://doi.org/10.1016/0009-2541(94)90059-0.

Mørk A., Elvebakk G., Forsberg A.W., Hounslow M.W., Nakrem H.A., Vigran J.O. \& Weitschat W. 1999. The type section of the Vikinghogda Formation: a new Lower Triassic unit in central and eastern Svalbard. Polar Research 18, 51-82, https://doi.org/10.1111/j.1751-8369.1999.tb00277.x.

Muckenhuber S., Nilsen F., Korosov A. \& Sandven S. 2016. Sea ice cover in Isfjorden and Hornsund, Svalbard (2000-2014) from remote sensing data. The Cryosphere 10, 149-158, https://doi.org/10.5194/tc-10-149-2016.

Nilsen F., Cottier F., Skogseth R. \& Mattsson S. 2008. Fjordshelf exchanges controlled by ice and brine production: the interannual variation of Atlantic Water in Isfjorden, Svalbard. Continental Shelf Research 28, 1838-1853, https:// doi.org/10.1016/j.csr.2008.04.015.

Prior D.B., Wiseman W.J Jr. \& Bryant W.R. 1981. Submarine chutes on the slopes of fjord deltas. Nature 290, 326-328, https://doi.org/10.1038/290326a0.

Rasmussen T.L., Forwick M. \& Mackensen A. 2012. Reconstruction of inflow of Atlantic Water to Isfjorden, Svalbard during the Holocene: correlation to climate and seasonality. Marine Micropaleontology 94-95, 80-90, https://doi. org/10.1016/j.marmicro.2012.06.008.

Rasmussen T.L., Thomsen E., Ślubowska M.A., Jessen S., Solheim A. \& Koç N. 2007. Paleoceanographic evolution of the SW Svalbard margin $\left(76^{\circ} \mathrm{N}\right)$ since $20,000{ }^{14} \mathrm{C}$ yr BP. Quaternary Research 67, 100-114, https://doi.org/10.1016/j. yqres.2006.07.002.

Reimer P.J., Bard E., Bayliss A., Beck J.W., Blackwell P.G., Ramsey C.B., Buck C.E., Cheng H., Edwards R.L. \& Friedrich M. 2013. IntCall3 and Marinel3 radiocarbon age calibration curves 0-50,000 years cal BP. Radiocarbon 55, 1869-1887, https://doi.org/10.2458/ azu_js_rc.55.16947.

Røthe T.O., Bakke J., Vasskog K., Gjerde M., D'Andrea W.J. \& Bradley R.S. 2015. Arctic Holocene glacier fluctuations reconstructed from lake sediments at Mitrahalvøya, Spitsbergen. Quaternary Science Reviews 109, $111-125$, https:// doi.org/10.1016/j.quascirev.2014.11.017.

Salvigsen O. 1984. Occurrence of pumice on raised beaches and Holocene shoreline displacement in the inner Isfjorden area, Svalbard. Polar Research 2, 107-1 13, https:// doi.org/10.3402/polar.v2il.6964.
Shanmugam G. 1997. The Bouma Sequence and the turbidite mind set. Earth-Science Reviews 42, 201-229, https://doi. org/10.1016/S0012-8252(97)81858-2.

Sarnthein M., van Kreveld S., Erlenkeuser H., Grootes P., Kucera M., Pflaumann U. \& Schulz M. 2003. Centennial-to-millennial-scale periodicities of Holocene climate and sediment injections off the western Barents shelf, $75^{\circ} \mathrm{N}$. Boreas 32, 447-461, https://doi. org/10.1080/03009480310003351.

Silva J.A. \& Bremner J.M. 1966. Determination and isotope-ratio analysis of different forms of nitrogen in soils: 5. Fixed ammonium. Soil Science Society of America Journal 30, 587-594, https://doi.org/10.2136/sssaj1966.03615995 $003000050017 x$.

Ślubowska M.A., Koç N., Rasmussen T.L. \& KlitgaardKristensen D. 2005. Changes in the flow of Atlantic Water into the Arctic Ocean since the last deglaciation: evidence from the northern Svalbard continental margin, $80^{\circ}$ N. Paleoceanography 20, PA4014, https://doi. org/10.1029/2005PA001141.

Ślubowska-Woldengen M., Rasmussen T.L., Koç N., Klitgaard-Kristensen D., Nilsen F. \& Solheim A. 2007. Advection of Atlantic Water to the western and northern Svalbard shelf since 17,500 cal yr BP. Quaternary Science Reviews 26, 463-478, https://doi.org/10.1016/j. quascirev.2006.09.009.

Stuiver M. \& Reimer P.J. 1993. Extended ${ }^{14} \mathrm{C}$ data base and revised CALIB $3.0{ }^{14} \mathrm{C}$ age calibration program. Radiocarbon 35, 215-230, https://doi.org/10.1017/S00338222 00013904.

Svendsen H., Beszczynska-Møller A., Hagen J.O., Lefauconnier B., Tverberg V., Gerland S., Ørbæk J.B., Bischof K., Papucci C., Zajaczkowski M., Azzolini R., Bruland O. \& Wiencke C. 2002. The physical environment of Kongsfjorden-Krossfjorden, an Arctic fjord system in Svalbard. Polar Research 21, 133-166, https://doi. org/10.1111/j.1751-8369.2002.tb00072.x.

Svendsen J.I., Elverhøi A. \& Mangerud J. 1996. The retreat of the Barents Sea Ice Sheet on the western Svalbard margin. Boreas 25, 244-256, https://doi. org/10.1111/j.1502-3885.1996.tb00640.x.

Svendsen J.I. \& Mangerud J. 1997. Holocene glacial and climatic variations on Spitsbergen, Svalbard. The Holocene 7, 45-57, https://doi.org/10.1177/095968369700700105.

Tjallingii R., Röhl U., Kölling M. \& Bickert T. 2007. Influence of the water content on x-ray fluorescence core-scanning measurements in soft marine sediments. Geochemistry, Geophysics, Geosystems 8, Q02004, https://doi. org/10.1029/2006GC001393.

van der Bilt W.G.M., D'Andrea W.J., Bakke J., Balascio N.L., Werner J.P., Gjerde M. \& Bradley R.S. 2018. Alkenone-based reconstructions reveal four-phase Holocene temperature evolution for High Arctic Svalbard. Quaternary Science Reviews 183, 204-213, https://doi.org/10.1016/j. quascirev.2016.10.006.

Weltje G.J. \& Tjallingii R. 2008. Calibration of XRF core scanners for quantitative geochemical logging of sediment cores: theory and application. Earth and Planetary 
Science Letters 274, 423-438, https://doi.org/10.1016/j. epsl.2008.07.054

Werner K., Müller J., Husum K., Spielhagen R.F., Kandiano E.S. \& Polyak L. 2016. Holocene sea subsurface and surface water masses in the Fram Strait-comparisons of temperature and sea-ice reconstructions. Quaternary Science Reviews 147, 194-209, https://doi.org/10.1016/j. quascirev.2015.09.007.

Weslawski J., Koszteyn J., Zajączkowski M., Wiktor J. \& Kwasniewski S. 1995. Fresh water in Svalbard fjord ecosystem. In H.R. Skjoldal et al. (eds.): Ecology of fjords and coastal waters. Pp. 229-241. Amsterdam: Elsevier Science.

Winkelmann D. \& Knies J. 2005. Recent distribution and accumulation of organic carbon on the continental margin west off Spitsbergen. Geochemistry, Geophysics, Geosystems 6, Q09012, https://doi.org/10.1029/2005GC000916.

Zajączkowski M. 2008. Sediment supply and fluxes in glacial and outwash fjords, Kongsfjorden and Adventfjorden, Svalbard. Polish Polar Research 29, 59-72.

Zajączkowski M., Nygård H., Hegseth E.N. \& Berge J. 2010. Vertical flux of particulate matter in an Arctic fjord: the case of lack of the sea-ice cover in Adventfjorden 2006-2007. Polar Biology 33, 223-239, https://doi. org/10.1007/s00300-009-0699-x.

Zajączkowski M. \& Włodarska-Kowalczuk M. 2007. Dynamic sedimentary environments of an Arctic glacier-fed river estuary (Adventfjorden, Svalbard). I. Flux, deposition, and sediment dynamics. Estuarine, Coastal and Shelf Science 74, 285-296, https://doi.org/10.1016/j.ecss.2007.04.015. 